Asian J. Med. Biol. Res. 2020, 6 (1), 16-21; doi: 10.3329/ajmbr.v6i1.46474

\author{
Asian Journal of \\ Medical and Biological Research \\ ISSN 2411-4472 (Print) 2412-5571 (Online) \\ www.ebupress.com/journal/ajmbr
}

\title{
Article \\ Performance of complete blood count (CBC) upon use of different anticoagulants in rats
}

Md. Mottaleb Ali ${ }^{1}$, Nilima Rubaba Azad ${ }^{1}$, Md. Iqramul Haque ${ }^{1}$, Khaled Mahmud Sujan ${ }^{1}$, Kazi Rafiqul Islam ${ }^{2}$ and Md. Kamrul Islam ${ }^{1} *$

${ }^{1}$ Department of Physiology, Faculty of Veterinary Science, Bangladesh Agricultural University, Mymensingh2202, Bangladesh

${ }^{2}$ Department of Pharmacology, Faculty of Veterinary Science, Bangladesh Agricultural University, Mymensingh-2202, Bangladesh

*Corresponding author: Professor Dr. Md. Kamrul Islam, Department of Physiology, Faculty of Veterinary Science, Bangladesh Agricultural University, Mymensingh-2202, Bangladesh. E-mail: k.physiol@bau.edu.bd

Received: 18 January 2020/Accepted: 05 March 2020/ Published: 31 March 2020

\begin{abstract}
Complete blood count (CBC) is used as an index of health status of human and different animals as well as to diagnose a variety of diseases. Therefore, there is a growing need of using the most suitable anticoagulant to obtain the most appropriate hemogram. The present study was designed to assess the effect of different anticoagulants viz. Heparin, Sodium Citrate and EDTA on complete blood count (CBC) in rat with a view to choosing the best suitable candidate among the common anticoagulants. A total of 30 samples out of which 10 were for each type anticoagulant were collected from 10 apparently healthy rats of Long Evans strain. From each rat $6 \mathrm{ml}$ of blood was drawn and subsequently divided into three different test tubes with three different anticoagulants. The samples were analyzed for their complete blood count (TEC, TLC, Hb, Hct, DLC, absolute leukocyte count, Red Cell Indices, RDW-SD, RDWCV, Platelet, MPV, PCT and PDW) using Sysmex XT-1800i Auto hematological analyzer. Results showed a significant $(\mathrm{p}<0.05)$ decrease in TLC, absolute neutrophil, and platelet count, and a significant $(\mathrm{p}<0.05)$ higher level of relative lymphocyte count in Sodium Citrate treated sample than with Heparin and EDTA. No significant changes were observed for RBC or erythrocyte indices among the three different groups. It can be concluded that samples treated with Sodium Citrate results in significant change in blood parameters. Therefore, it is better to use Heparin and EDTA than Sodium Citrate for complete blood count (CBC).
\end{abstract}

Keywords: complete blood count (CBC); heparin; sodium citrate; EDTA; rat

\section{Introduction}

Blood is a connective tissue made up of cells suspended in a fluid medium known as plasma which is made up of minerals, salt, vitamins, coagulation factors and organic elements. The cellular portion of blood is composed of Erythrocytes (RBC), Leukocytes (WBC) and Platelets (Wood et al., 1999). In present days Complete blood count (CBC) is one of the most choices of test for blood that is frequently used in veterinary medical profession. CBC consists of investigation of cellular content of blood mainly white blood cell, thrombocytes and the red blood cell with related parameters (packed cell volume, hemoglobin concentration) (Wood et al., 1999). To carry out this operation the whole blood needs to be collected in a suitable anticoagulant to prevent undesirable clotting. Several anticoagulants e.g. EDTA (Ethylene Diamine Tetraacetic acid), heparin, sodium citrate, oxalate, ACD (Acid Citrate Dextrose), CPD (Citrate Phosphate Dextrose) are used for collection and routine laboratory analysis. These anticoagulants have effects on hematological parameters. Heparin is a naturally synthesized endogenous anticoagulant which prevents blood coagulation in vivo as well as in vitro. It inhibits 
the conversion of prothrombin into active thrombin, and thus prevents conversion of fibrinogen into fibrin (Witeska and Wargocka, 2011).The mechanism of action of EDTA and sodium citrate is based on inhibition of thrombocyte aggregation and various reactions of hemostatic cascade due to chelation of free $\mathrm{Ca}^{2+}$ ions (Witeska and Wargocka, 2011). However, there is very little evidence of the effects of anticoagulants on blood parameters of various animals. In human hematology, it is assumed that heparin should not be used for blood smears due to blue staining background, or for WBC count due to clotting leukocytes, while EDTA is inappropriate for evaluation of erythrocyte osmotic fragility, and its excess may cause damage to the blood cells (Marianska et al., 2003). In mammals, $\mathrm{K}_{2}$ EDTA is the recommended anticoagulant for storing blood samples for hematologic testing. In many domestic species, heparin alters leukocyte morphology, provides poorer staining quality to the cells, and does not prevent platelet aggregation (Knoll, 2000). Most recently; a study in macaws compared the temporal effects of 3 commonly used anticoagulants. However the use of heparin coated syringes in this study limited the ability to fully ascertain the effect of individual anticoagulants (Harr et al., 2005). Citrate and EDTA are recommended for samples which are analyzed by automated methods. Heparin has been advocated for use with blood samples from species with nucleated RBCs based on the perceived observation of hemolysis in EDTA-preserved samples in some reptiles and birds. The effects of various types of anticoagulants in hematology were studied in various animal, bird and fish species in a scattered way by few researchers and still the thorough investigation in this area is of greater importance. Therefore, the present study was undertaken to determine the effects of three commonly used anticoagulants Heparin, Sodium Citrate and EDTA on complete blood count $(\mathrm{CBC})$ of rats.

\section{Materials and Methods}

The study was conducted in the Department of Physiology, Faculty of Veterinary science, Bangladesh Agricultural University, Mymensingh.

\subsection{Experimental animals}

A total of 15 rats of Long Evans strain aged between 18-20 days were purchased from International Center for Diarrheal Disease Research, Bangladesh (icddr'b), Mohakhali, Dhaka and reared in the compartmentalized square wooden cages wrapped with wire mesh under controlled conditions of temperature $(26-30)^{\circ} \mathrm{C}$ and relative humidity of 70-80\% with natural day light.

\subsection{Preparation of the experimental laboratory}

The laboratory was cleaned and washed with disinfectant. Then it was left empty for 3 days before placing the experimental rats. All necessary equipments were set properly for proper handling and care of the animals.

\subsection{Experimental design}

After acclimatization, all (15) rats were reared in same environmental condition and out of 15 rats 10 were randomly chosen at the age between 45-48 days. Each rat is designated as 1,2,3, and so on. For each rat 3 tubes were used to collect blood sample which were marked as 1.a, 1.b, 1.c for rat no.1, 2.a, 2.b, 2.c for rat no.2 and so on where 'a' for EDTA, 'b' for Heparin and 'c' for Citrate.

\subsection{Management practices}

Commercial rat pellet was collected from icddr'b and was supplied to all rats throughout the experiment. The feed was supplied twice daily and fresh potable drinking water was available. Proper hygienic and sanitary measurement was taken during the experimental period.

\subsection{Blood sample collection}

Before sample collection the rats were kept fasting overnight. Blood samples were collected from rats under general anesthesia by using diethyl ether. A total of 30 samples out of which 10 were for each type anticoagulant were collected from 10 apparently healthy rats. From each rat $6 \mathrm{ml}$ of blood was drawn and subsequently divided into three different test tubes commercially treated with three different anticoagulants. $\mathrm{K}_{3}$ EDTA $(3.6 \mathrm{mg} / 2 \mathrm{ml}$ ), Lithium Heparin and Sodium citrate (3.2\%) containing commercially available blood 
collection tubes were used for sampling. Under general anesthesia the abdomen of the animal was opened and blood was drawn from the bifurcation of the abdominal aorta. Prompt transfer of the blood into the tube and proper mixing with the anticoagulant was ensured immediate after collection. Then each and every samples were sent to laboratory for the measurement of hematological parameters viz; RBC, WBC, platelet count, DLC, $\mathrm{Hb}$ level, hematocrit value and measurement of MCV, MCH, MCHC. All samples were analyzed by Sysmex XT- 1800i Automated Hematology Analyzer.

\subsection{Statistical analysis}

One-way analysis of variance (ANOVA) was used to determine the effect of different anticoagulant on blood parameters. Bonferroni's multiple comparison tests was applied for post-hoc comparison. All statistical analyses were performed using a commercial statistical program- SPSS.

\section{Results and Discussion}

\subsection{Effects on total erythrocyte count and erythrocyte indices}

The results placed in Table 1 show no significant differences in total RBC count and Hb level among three anticoagulant samples. These findings were partially similar with Mafuvadze et al. (2007) findings but differ from Faggio et al. (2014) who reported a higher level of $\mathrm{Hb}$ in EDTA sample as compared to heparin and citrate sample. In contrast, it also differs from the findings of Muro et al. (1998) who reported a lower level of RBC in EDTA sample. The hematocrit (Hct) value of sodium citrate is $35.95 \pm 1.48$ and is significantly $(\mathrm{P}<0.01)$ lower than that of the heparinized sample $(41.41 \pm 3.02)$ and is closely agreeable with the findings of Harr et al. (2005). The MCV showed significant $(\mathrm{P}<0.01)$ lower level of its value in the sample with sodium citrate compared to EDTA and heparinized sample that is related with findings of Uko et al. (1996) and Maqbool et al. (2014). The MCHC is also significantly $(\mathrm{P}<0.05)$ lower in sodium citrate than that of EDTA and heparin sample. The values of $\mathrm{MCH}$ and red cell distribution width (RDW \%) also shows no significant variation among the samples preserved in different anticoagulants.

\subsection{Effects on total leukocyte count and absolute count of its cell component}

The absolute count of total leukocyte in citrated blood sample $(5.81 \pm 1.56)$ is significantly $(\mathrm{P}<0.01)$ lower than that in the EDTA $(10.31 \pm 2.03)$ and heparinized sample $(8.99 \pm 2.65)$ which agrees the findings of Faggio et al. (2004). The result represented a significant decrease in the count of neutrophil $(\mathrm{P}<0.01)$, lymphocyte $(\mathrm{P}<0.05)$, monocyte $(\mathrm{P}<0.01)$ and eosinophil $(\mathrm{P}<0.01)$ in citrated blood sample compared to samples with EDTA and heparin as shown in Table 2. This finding supports the previous report of Adeyemo et al. (2009); Faggio et al. (2004) and Hanley et al. (2004) except the value of monocyte count. Neither of the anticoagulants showed significant effect on absolute count of basophil.

\subsection{Effects on differential leukocyte count}

The values of differential leukocyte count are placed in Table 3 showing a significant $(\mathrm{P}<0.01)$ decrease in relative count of neutrophil, monocyte and eosinophil in case of sample preserved in sodium citrate but a significant $(\mathrm{P}<0.05)$ increase in relative lymphocyte count that is similar with the findings of Guzman et al. (2008). It revealed that the difference in anticoagulant for preservation of blood sample does not matter in relative count of basophil.

\subsection{Effects on platelet count and its indices}

Effects on Platelet count and its indices are placed in the Table 4. The value of MPV (fL) showed a significant $(\mathrm{P}<0.05)$ level of decrease in citrated sample $(1.12 \pm 2.96)$ compared to EDTA $(5.77 \pm 3.95)$ and heparinized $(6.44$ $\pm 2.90)$ sample. The findings of this study showed that difference in choosing different anticoagulant do not affect platelet count and PCT (\%) measurement. These findings were disagree with McShine et al. (1990) who reported a lower platelet count in citrated sample than those in EDTA sample. 
Asian J. Med. Biol. Res. 2020, 6 (1)

Table 1. Effects of $K_{3} E D T A$, heparin and sodium citrate on total erythrocyte count and erythrocyte indices.

\begin{tabular}{|c|c|c|c|c|c|}
\hline \multirow[t]{2}{*}{ Parameters } & \multicolumn{3}{|c|}{$\begin{array}{c}\text { Mean } \pm \text { SD } \\
\text { (Range) }\end{array}$} & \multirow[t]{2}{*}{$\begin{array}{l}\text { Level of } \\
\text { significance }\end{array}$} & \multirow[t]{2}{*}{$P$ value } \\
\hline & $\mathrm{K}_{\mathbf{3}}$ EDTA & Heparin & Sodium citrate & & \\
\hline $\mathrm{RBC}(\mathrm{M} / \mu \mathrm{L})$ & $\begin{array}{l}6.11 \pm 0.58 \\
(4.89-6.66)\end{array}$ & $\begin{array}{l}6.62 \pm 0.65 \\
(5.42-7.25)\end{array}$ & $\begin{array}{l}6.16 \pm 0.28 \\
(5.75-6.50)\end{array}$ & NS & 0.172 \\
\hline $\mathrm{Hb}(\mathrm{g} / \mathrm{dL})$ & $\begin{array}{l}13.43 \pm 0.71 \\
(12.34-14.50)\end{array}$ & $\begin{array}{l}14.05 \pm 1.26 \\
(12.00-15.30)\end{array}$ & $\begin{array}{l}12.96 \pm 0.49 \\
(12.00-13.40)\end{array}$ & NS & 0.095 \\
\hline Hct (\%) & $\begin{array}{l}39.85 \pm 3.82^{a b} \\
(32.30-43.10)\end{array}$ & $\begin{array}{l}41.41 \pm 3.02^{\mathrm{a}} \\
(37.00-45.10) \\
\end{array}$ & $\begin{array}{l}35.95 \pm 1.48^{b} \\
(32.90-37.20)\end{array}$ & $* *$ & 0.008 \\
\hline $\mathrm{MCV}(\mathrm{fL})$ & $\begin{array}{l}65.27 \pm 1.91^{\mathrm{a}} \\
(63.02-68.72) \\
\end{array}$ & $\begin{array}{l}62.80 \pm 4.09^{\mathrm{a}} \\
(57.22-68.32) \\
\end{array}$ & $\begin{array}{l}58.34 \pm 2.06^{b} \\
(55.22-61.92) \\
\end{array}$ & $* *$ & 0.001 \\
\hline $\mathrm{MCH}(\mathrm{pg})$ & $\begin{array}{l}22.12 \pm 1.44 \\
(21.22-25.24)\end{array}$ & $\begin{array}{l}21.24 \pm 0.74 \\
(20.02-22.12)\end{array}$ & $\begin{array}{l}21.05 \pm 0.47 \\
(20.42-21.82)\end{array}$ & NS & 0.121 \\
\hline $\mathrm{MCHC}(\mathrm{g} / \mathrm{dL})$ & $\begin{array}{l}33.76 \pm 2.10^{\mathrm{a}} \\
(31.40-38.14)\end{array}$ & $\begin{array}{l}33.91 \pm 1.22^{\mathrm{a}} \\
(32.40-35.40)\end{array}$ & $\begin{array}{l}36.04 \pm 0.65^{b} \\
(35.20-37.04)\end{array}$ & $*$ & 0.04 \\
\hline RDW-CV (\%) & $\begin{array}{l}14.6 \pm 0.68 \\
(13.70-15.60)\end{array}$ & $\begin{array}{l}15.14 \pm 1.04 \\
(13.90-16.71)\end{array}$ & $\begin{array}{l}15.28 \pm 0.73 \\
(14.30-16.31)\end{array}$ & NS & 0.290 \\
\hline
\end{tabular}

$* *=$ Significant at $\mathrm{P}<0.01 ; *=$ Significant at $\mathrm{P}<0.05 ; \mathrm{NS}=$ Non significant

Table 2. Effects of $K_{3}$ EDTA, heparin and sodium citrate on total leukocyte count and absolute count of its cells component.

\begin{tabular}{|c|c|c|c|c|c|}
\hline \multirow[t]{2}{*}{ Parameters } & \multicolumn{3}{|c|}{$\begin{array}{c}\text { Mean } \pm \text { SD } \\
\text { (Range) }\end{array}$} & \multirow[t]{2}{*}{$\begin{array}{l}\text { Level of } \\
\text { significance }\end{array}$} & \multirow[t]{2}{*}{ P value } \\
\hline & $\mathbf{K}_{3}$ EDTA & Heparin & Sodium citrate & & \\
\hline $\begin{array}{l}\text { WBC } \\
(\mathrm{K} / \mu \mathrm{L})\end{array}$ & $\begin{array}{l}10.31 \pm 2.03^{\mathrm{a}} \\
(8.29-13.57)\end{array}$ & $\begin{array}{l}8.99 \pm 2.65^{\mathrm{a}} \\
(5.10-13.0)\end{array}$ & $\begin{array}{l}5.81 \pm 1.56^{b} \\
(3.67-8.11)\end{array}$ & $* *$ & 0.003 \\
\hline Neutrophil $(\mathrm{K} / \mu \mathrm{L})$ & $\begin{array}{l}2.20 \pm 0.37^{\mathrm{a}} \\
(1.60-2.66)\end{array}$ & $\begin{array}{l}1.72 \pm 1.33^{\mathrm{a}} \\
(0.28-4.32)\end{array}$ & $\begin{array}{l}0.36 \pm 0.32^{b} \\
(0.05-0.81)\end{array}$ & $* *$ & 0.002 \\
\hline $\begin{array}{l}\text { Lymphocyte } \\
(\mathrm{K} / \mu \mathrm{L})\end{array}$ & $\begin{array}{l}7.59 \pm 1.84^{\mathrm{a}} \\
(5.45-11.01)\end{array}$ & $\begin{array}{l}6.96 \pm 1.37^{\mathrm{ab}} \\
(4.74-8.22)\end{array}$ & $\begin{array}{l}5.36 \pm 1.28^{b} \\
(3.26-7.15)\end{array}$ & $*$ & 0.041 \\
\hline Monocyte $(\mathrm{K} / \mu \mathrm{L})$ & $\begin{array}{l}0.20 \pm 0.05^{\mathrm{a}} \\
(0.13-0.32)\end{array}$ & $\begin{array}{l}0.17 \pm 0.12^{\mathrm{a}} \\
(0.03-0.37)\end{array}$ & $\begin{array}{l}0.03 \pm 0.03^{\mathrm{b}} \\
(0.01-0.09)\end{array}$ & $* *$ & 0.013 \\
\hline Eosinophil $(\mathrm{K} / \mu \mathrm{L})$ & $\begin{array}{l}0.30 \pm 0.26^{\mathrm{a}} \\
(0.05-0.84)\end{array}$ & $\begin{array}{l}0.10 \pm 0.04^{\mathrm{ab}} \\
(0.04-0.15)\end{array}$ & $\begin{array}{l}0.03 \pm 0.02^{b} \\
(0.00-0.05)\end{array}$ & $* *$ & 0.011 \\
\hline Basophils $(\mathrm{K} / \mu \mathrm{L})$ & $\begin{array}{l}0.014 \pm 0.005 \\
(0.01-0.02)\end{array}$ & $\begin{array}{l}0.014 \pm 0.007 \\
(0.00-0.02)\end{array}$ & $\begin{array}{l}0.007 \pm 0.004 \\
(0.00-0.01)\end{array}$ & NS & 0.068 \\
\hline
\end{tabular}

$* *=$ Significant at $\mathrm{P}<0.01 ; *=$ Significant at $\mathrm{P}<0.05 ; \mathrm{NS}=$ Non significant

Table 3. Effects of $K_{3} E D T A$, heparin and sodium citrate on differential leukocyte count.

\begin{tabular}{|c|c|c|c|c|c|}
\hline \multirow[t]{2}{*}{ Parameters } & \multicolumn{3}{|c|}{$\begin{array}{c}\text { Mean } \pm \text { SD } \\
\text { (Range) }\end{array}$} & \multirow[t]{2}{*}{$\begin{array}{l}\text { Level of } \\
\text { significance }\end{array}$} & \multirow[t]{2}{*}{$P$ value } \\
\hline & $\mathrm{K}_{\mathbf{3}}$ EDTA & Heparin & Sodium citrate & & \\
\hline Neutrophil (\%) & $\begin{array}{l}21.94 \pm 5.13^{\mathrm{a}} \\
(15.54-31.24)\end{array}$ & $\begin{array}{l}17.15 \pm 9.02^{\mathrm{a}} \\
(5.54-33.24)\end{array}$ & $\begin{array}{l}5.84 \pm 4.29^{b} \\
(1.02-10.74)\end{array}$ & $* *$ & 0.001 \\
\hline Lymphocyte (\%) & $\begin{array}{l}73.14 \pm 5.10^{\mathrm{a}} \\
(65.74-81.14)\end{array}$ & $\begin{array}{l}79.14 \pm 9.72^{\mathrm{a}} \\
(63.24-92.94)\end{array}$ & $\begin{array}{l}92.93 \pm 4.94^{b} \\
(87.24-98.78)\end{array}$ & *** & 0.007 \\
\hline Monocyte (\%) & $\begin{array}{l}1.96 \pm 0.51^{\mathrm{a}} \\
(1.34-2.94)\end{array}$ & $\begin{array}{l}1.82 \pm 0.94^{\mathrm{a}} \\
(0.64-3.34)\end{array}$ & $\begin{array}{l}0.62 \pm 0.48^{\mathrm{b}} \\
(0.20-1.14)\end{array}$ & $* *$ & 0.005 \\
\hline Eosinophil (\%) & $\begin{array}{l}2.81 \pm 2.22^{a} \\
(0.54-6.84)\end{array}$ & $\begin{array}{l}1.12 \pm 0.33^{\mathrm{ab}} \\
(0.74-1.54)\end{array}$ & $\begin{array}{l}0.44 \pm 0.31^{b} \\
(0.00-0.94)\end{array}$ & $* *$ & 0.01 \\
\hline Basophils (\%) & $\begin{array}{l}0.14 \pm 0.00 \\
(0.14-0.14)\end{array}$ & $\begin{array}{l}0.15 \pm 0.07 \\
(0.04-0.24)\end{array}$ & $\begin{array}{l}0.16 \pm 0.11 \\
(0.00-0.34)\end{array}$ & NS & 0.865 \\
\hline
\end{tabular}

\footnotetext{
$* *=$ Significant at $\mathrm{P}<0.01 ; *=$ Significant at $\mathrm{P}<0.05 ; \mathrm{NS}=$ Non significant
} 
Asian J. Med. Biol. Res. 2020, 6 (1)

Table 4. Effects of $K_{3} E D T A$, heparin and sodium citrate on platelet count and its indices.

\begin{tabular}{|c|c|c|c|c|c|}
\hline \multirow[t]{2}{*}{ Parameters } & \multicolumn{3}{|c|}{$\begin{array}{c}\text { Mean } \pm \text { SD } \\
\text { (Range) }\end{array}$} & \multirow[t]{2}{*}{$\begin{array}{l}\text { Level of } \\
\text { significance }\end{array}$} & \multirow[t]{2}{*}{$P$ value } \\
\hline & $\mathrm{K}_{\mathbf{3}}$ EDTA & Heparin & Sodium citrate & & \\
\hline Platelet $(\mathrm{K} / \mu \mathrm{L})$ & $\begin{array}{l}299.14 \pm 364.76 \\
(1.00-777)\end{array}$ & $\begin{array}{l}319.86 \pm 299.18 \\
(30-715)\end{array}$ & $\begin{array}{l}79.57 \pm 177.92 \\
(08-483)\end{array}$ & NS & 0.25 \\
\hline MPV (fL) & $\begin{array}{l}5.77 \pm 3.95^{\mathrm{a}} \\
(00-8.44)\end{array}$ & $\begin{array}{l}6.44 \pm 2.90^{\mathrm{a}} \\
(00-8.24)\end{array}$ & $\begin{array}{l}1.12 \pm 2.96^{\mathrm{b}} \\
(00-7.84)\end{array}$ & $*$ & 0.02 \\
\hline PCT (\%) & $\begin{array}{l}0.66 \pm 0.74 \\
(00-2.19)\end{array}$ & $\begin{array}{l}0.24 \pm 0.24 \\
(00-0.58)\end{array}$ & $\begin{array}{l}0.05 \pm 0.13 \\
(00-0.37)\end{array}$ & NS & 0.06 \\
\hline
\end{tabular}

$* *=$ Significant at $\mathrm{P}<0.01 ; *=$ Significant at $\mathrm{P}<0.05 ; \mathrm{NS}=$ Non significant

\section{Conclusions}

The three anticoagulants selected for this study have been successfully used in complete blood count and laboratory analysis. It was observed that Hct and MCV showed a marked decrease $(\mathrm{P}<0.01)$ in their value in citrated sample as compared to heparin and EDTA sample. The value of total leukocyte count (TLC) and absolute count of netrophil, monocyte and eosinophil showed a highly significant $(\mathrm{P}<0.01)$ decrease in citrated sample than that of EDTA and heparin sample. In differential leukocyte count the relative count of all parameters neutrophil, lymphocyte, monocyte, and eosinophil showed a significantly $(\mathrm{P}<0.01)$ lower level of their values in citrated sample. The difference anticoagulant had no significant effect on total platelet count and PCT (\%) except the MPV (fL) value in citrated sample showed a significantly $(\mathrm{P}<0.05)$ lower value as compared to EDTA and heparinized samples. It can be concluded that samples treated with sodium citrate result in significant change in blood parameters, therefore it is better to use heparin and EDTA than sodium citrate.

\section{Acknowledgements}

Ministry of Science and Technology, Government of the People's Republic of Bangladesh.

\section{Conflict of interest}

None to declare.

\section{References}

Adeyemo OK, OO Okwilagwe and F Ajani, 2009. Comparative assessment of sodium EDTA and heparin as anticoagulants for the evaluation of haematological parameters in cultured and feral african catfish (Clarias gariepinus). Brazilian Journal of Aquatic Science and Technology, 13: 19-24.

Faggio C, F Arfuso, G Piccione, A Zumbo and F Fazio, 2014. Effect of three different anticoagulants and storage time on haematological parameters of Mugil cephalus. (Linneus, 1758). Turk. J. Fish. \& Aquat. Sci., 14: 615-621.

Hanley CS, SJ Hernandez-Divers, S Bush and KS Latimer, 2004. Comparison of the effect of dipotassium ethylene diaminetetraacetic acid and lithium heparin on hematologic values in the green iguana (Iguana iguana). J. Zoo Wildlife Med., 35: 328-332.

Harr KE, RE Raskin and DJ Heard, 2005. Temporal effects of 3 commonly used anticoagulants on hematologic and biochemical variables in blood samples from macaws and Burmese pythons. Vet. Clin. Pathol., 34: 383388.

Knoll JS, 2000. Clinical automated hematology systems. In: Feldman BF, Zink1 JG, Jain NC, eds. Schalm's Veterinary Hematology, 5th edn. Philadelphia, PA: Lippincott, Williams, \& Wilkins; 2000: 3-11.

Mafuvadze B and KH Erlwanger, 2007. The effect of EDTA, heparin and storage on the erythrocyte osmotic fragility, plasma osmolality and haematocrit of adult ostriches (Struthio camelus). Vet. Arhiv., 77: 427-434.

Maqbool A, I Ahmed and ZA Sheikh, 2014. Effects of two commonly used anticoagulants on hematology and erythrocyte morphology of rainbow trout (Oncorhynchus mykiss). Int. J. Fish. Aquat. Stud., 2: 239-243.

Mariańska B, J Fabijańska-Mitek and J Windyga, 2003. Laboratory hematological analyses. Manual for medicine students. Wyd. Lek. PZWL, Warszawa.

McShine RL, S Sibinga and B Brozovic, 1990. Differences between the effects of EDTA and citrate anticoagulants on platelet count and mean platelet volume. Clin. Lab. Haematol., 12: 277-285.

Muro J, R Cuenca, J Pastor, L Vinas and S Lavin, 1998. Effects of lithium heparin and tripotassium EDTA on hematologic values of Hermann's tortoises (Testudo hermanni). J. Zoo Wildlife Med., 29: 40-44. 
Uko OJ and AM Ataja, 1996. Effects of anticoagulants and storage $\left(4{ }^{\circ} \mathrm{C}\right)$ on packed cell volume (PCV) of Nigerian domestic fowl (Gallus domesticus) and guinea fowl (Numida meleagris). Br. Poult. Sci., 37: 9971002.

Witeska M and W Wargocka, 2011. Disodium EDTA used as anticoagulant causes hemolysis in common carp blood. Turk. J. Vet. Anim. Sci., 35: 99-104.

Wood BL, J Andrew, S Miller and DE Sabath, 1999. Refrigerated storage improves stability of the complete blood count and automated differential. Am. J. Clin. Pathol., 112: 687-695. 